\title{
The Long-term Consequences of the Irish Marriage Bar
}

\author{
by \\ Irene Mosca*, Maynooth University, Ireland \\ Robert E. Wright, University of Glasgow, Scotland
}

July, 2019

\begin{abstract}
A Marriage Bar is the requirement that women in certain jobs must leave that job when they marry. Ireland had a Marriage Bar in place until the 1970s. In 2014/2015, women participating in the The Irish Longitudinal Study on Ageing were asked-for the first time in a nationally-representative survey-specific questions about their experience of the Marriage Bar. In this paper, we use the information from the TILDA respondents for two purposes. The first is to investigate the extent of the Marriage Bar in Ireland. Our analysis suggests that the Marriage Bar was widespread and not confined to specific sectors or occupations (such as the Civil Service). The second purpose is to investigate the long-term consequences of the Marriage Bar. We do so by comparing the outcomes of women who were affected by the Marriage Bar with the outcomes of women who were not affected by the Marriage Bar. Regression analysis shows that women affected by the Marriage Bar have shorter working lives, lower individual income but higher household wealth at present, more children and more educated children. However, there are no statistically significant differences in the current health status of the two groups of women. The differences in long-term outcomes do not appear to be confounded by the endogeneity of marriage, education, employment and occupational choices.
\end{abstract}

JEL: J71, J78, J24

Key words: Marriage Bar, Ireland, discrimination

*Corresponding author: Irene Mosca, Maynooth University, Ireland. E-mail: irene.mosca@mu.ie Tel: +353 (0)1 4747139 


\section{The Long-term Consequences of the Irish Marriage Bar}

"The history of the Marriage Bar cannot be understood in isolation from the society that produced it".

Eoin O’Leary's (1987)

\section{Introduction}

A Marriage Bar is the requirement that women working in certain jobs must leave that job when they marry. In the twentieth century, Marriage Bars were not unusual internationally. For example, Marriage Bars were in place in Germany, the Netherlands, the United Kingdom and the United States. Ireland also had a Marriage Bar. In most countries, they were abolished in the $1950 \mathrm{~s}$ at the latest. Ireland's Marriage Bar is somewhat unique in this respect since it was only abolished in the 1970s. This means that many of the women who were affected by it are still alive. Most of the women affected by the Marriage Bar in the other countries are likely to have died or to be very old. Therefore Ireland provides a "last chance" opportunity to research the effects of what was effectively a policy of institutionalised gender discrimination.

Irish women who were affected by the Marriage Bar are likely to be included in current or recent social surveys. However, we are aware of only one survey where women were asked questions about their personal experience of the Marriage Bar. This is The Irish Longitudinal Study on Ageing (TILDA). TILDA is a nationally representative sample of community-dwelling individuals aged 50 and above in Ireland. At wave 3 of data collection (2014/2015), TILDA female respondents were specifically asked if "they ever had to leave a job because of the Marriage Bar". If their answer was "yes", they were also asked questions about the job they had to leave. In this paper, we combine this information with other information provided by TILDA respondents on past and current aspects of their lives to answer a number of questions which to date have remained unanswered in the literature.

Our analysis is three-fold. First, TILDA data is used to investigate how widespread the Marriage Bar was in Ireland and which jobs and sectors were most affected by it. Second, TILDA data is used to investigate the long-term consequences of the Marriage Bar. This is achieved by comparing the outcomes of women who were affected by the Marriage Bar with the outcomes of women who were not. Four groups of outcomes are considered: (1) family-related; (2) labour market-related; (3) economics-related and (4) health-related. Third, census data is used to investigate 
whether the presence of a Marriage Bar affected the behaviour of women. One might expect that a Marriage Bar would affect decisions relating to marriage, education, employment and occupation. This is important because if this is found to be true, the estimates of the effect of Marriage Bar on long-term outcomes might be biased.

There are three main findings. The first is that the Marriage Bar was widespread and was not confined to specific sectors or occupations. The second is that there are some differences in long-term outcomes between women affected and not affected by the Marriage Bar. Most notably, women affected by the Marriage Bar have shorter working lives, lower individual income but higher household wealth at the time of interview, more children and more educated children. However, there appear to be no differences in the physical, mental and cognitive health at time of interview between women affected and not affected by the Marriage Bar. The third finding is that there is no evidence that the Marriage Bar altered women's behaviour, with respect to marriage, education, employment and occupation, in a major way.

The remainder of this paper is organized as follows. Section 2 is a description of the Irish Marriage Bar. Section 3 is the analysis of TILDA data aimed at evaluating who was affected by the Marriage Bar. This section also includes a regression analysis aimed at evaluating the long-term outcomes of women affected and not affected by the Marriage Bar. Section 4 is the analysis of published and micro-level census data aimed at evaluating whether the behaviour of women was affected by the presence of the Marriage Bar. Conclusions follow in Section 5. This section also reviews the current position of the women who were affected by the Marriage Bar in Ireland.

\section{The Irish Marriage Bar}

The Government of Ireland introduced a Marriage Bar in the 1920s, first in the civil service. More specifically, the 1924 Civil Service Regulation Act stated that: “...female civil servants holding established posts will be required on marriage to resign from the civil service". In 1932, coverage was expanded to include primary school teachers. A letter from the Department of Education was delivered to the Irish Teachers National Organisation (the largest teachers' trade union in Ireland), stating that female primary school teachers are required to leave their job when they marry. The Marriage Bar in the civil service was bolstered by the 1956 Civil Service Regulation Act. The requirement became: “...women employed in positions in the civil 
service, other than those employed in certain excluded (non-pensionable) posts, are required to retire on marriage".

The Marriage Bar was not legally-binding in the sense that private sector and state-sponsored employers were not required to apply it. However, it appears that the practice of ending the employment of women when they married was widespread (Connolly, 2003; The Irish Times, 1975). For example, it was practised by local authorities, health boards and state-sponsored bodies such as Córas Iompair Éireann (the national public transport provider) and Aer Lingus (the national airline). Most banks and financial institutions adopted a Marriage Bar. It is difficult to establish how widespread it was in the private sector. However, the two large private sector employers, Jacobs Biscuits and Guinness Brewers, required female employees to leave when they married (Connolly, 2003; Muldowney, 2007). Because the government introduced the Marriage Bar in the first place, private sector employers were legitimised to dismiss women at marriage.

It was common for private sector employers to include a clause in their letters of appointment stating that employment would be terminated at marriage (The Journal, 2014). Women who had to resign at marriage were also often re-employed by the same employer in temporary capacity, for example during the lunch hour rush period (CSW, 1972). Often female employees were allowed to remain in employment for a certain period of time after marriage. The length of stay after married varied, but, in general, did not appear to exceed two years. In the majority of cases, the period of stay after marriage was in a purely temporary capacity. Where pension schemes operated, married women were precluded from continuing in the scheme (CSW, 1972). Quantitative evidence (discussed below) suggests that the Marriage Bar had the largest impact on women working in clerical and skilled occupations. Qualitative evidence indicates that the Marriage Bar also impacted on women in unskilled occupations (e.g. Kiely and Leane, 2012).

There are a number of reasons behind the introduction of the Marriage Bar in Ireland. One reason was the "belief" that a "woman's place is in the home". This was reflected in the Second Constitution of Ireland, which came into effect in 1937. Article 41.2 states that "mothers shall not be obliged by economic necessity to engage in labour to the neglect of their duties in the home." Another reason was to reduce male unemployment, which was high in Ireland at the time, by limiting households to one income earner: "one man, one job" (Redmond and Harford, 2010). 
Five reasons were given by the Department of Education for the introduction of the Marriage Bar for primary school teachers in 1932. First, women could not satisfactorily attend to the duties of both home and work. Second, married women teachers restricted opportunities for other women and created social tensions if married to a farmer, shopkeeper or teacher. Third, maternity leave created difficulties for pupils and staff. Fourth, women teachers generally married at 31 or 32 years of age, giving the State an adequate ten years of service for its investment in training. Fifth, after slight losses initially, the new regulation would be self-financing (O'Leary, 1987, p. 50).

Similar reasons were used to justify Marriage Bars in other countries. For example, in the UK there were two main reasons for why women should leave the civil service when they married. The first was that single women were more reliable and more geographically mobile than married women. The second was that even if the Marriage Bar was not legally-binding, it was expected that women would resign when they married or at the latest when they became pregnant (The Spectator, 1946). Goldin (1990, p.171) argued that there were also two main explanations for the Marriage Bar in the United States. The first was that the Marriage Bar served to maintain a threatened status-quo by keeping middle-class women in the home to take care of their families. The second was that the Marriage Bar was a socially acceptable way of terminating the employment of young women whose wages would eventually exceed their addition to firm revenue.

It is also important to note that occupational sex segregation was high in Ireland when the Marriage Bar was in place. Occupational sex segregation reflects the extent to which women are employed in typically female occupations and men are employed in typically male occupations (Russell et al., 2017). Walsh (1971) and Russell at el. (2017) report that in 1966, over a quarter of women were employed in occupations that were at least 90 per cent female. These were concentrated in seven occupations: sewers, typists, boarding housekeepers, housekeepers, maids, nurses and probation nurses. Evidence shows that occupational sex segregation has decreased to some extent over time. For example, of all those gainfully occupied (at work or unemployed) in personal service occupations in 1946, $83 \%$ were females and $17 \%$ were males (CSO, 2000). The proportion of females occupied in personal service occupations decreased to $68 \%$ in 1971 and to $63 \%$ in 1986 . Personal service occupations include private domestic service and service in hotels, restaurants and cafes, lodging and boarding houses, laundries, hairdressing and welfare and charitable organisations. 
A common feature of the Marriage Bar in Ireland and in other countries was the so-called "marriage gratuity". This was money given to women at marriage, which was often presented to them by a member of senior management (Connolly, 2003). Leaving employment to marry was viewed as positive event that should be celebrated since the bride-to-be no longer has to work. It was similar in spirit of "receiving a gold watch on retirement", where retirement was viewed as a positive event that was celebrated because the retiree no longer has to work. The marriage gratuity was mentioned by many of the 42 women, who held a variety of jobs in the period 1930 to 1960, interviewed by Kiely and Leane (2012). One of the women, who was a factory worker in the 1950 s, was given $£ 10$ when she left work. In her words, “ $£ 10$ was a lot back then". Another woman, who was a teacher in 1955, received $£ 120$. In her words, "she owned it all' (Kiely and Leane, 2012, p. 91). Teachers and civil servants needed a minimum of seven years of service to qualify for the marriage gratuity (O'Leary, 1987). For teachers, the marriage gratuity was equal to one month's salary per year of service, or a year's salary, whichever was the lesser (O'Leary, 1987).

The Marriage Bar for primary school teachers was abolished in June 1958. The Marriage Bar, along with a declining number of nuns, had caused shortages of trained female teachers. In 1970, a Commission was established by the Irish government: "to examine and report on the status of women in Irish society and to make recommendations on the steps necessary to ensure the participation of women on equal terms and conditions with men" (CSW, 1972). Responding to the pressure for change from the Commission, and from the requirements of the European Union, the Marriage Bar was abolished in 1973 in the civil service (Russell at al., 2017). Beginning in 1974, it was abandoned by local authorities and health boards.

In 1977, discrimination in employment on the grounds of sex or marital status was made illegal by the Employment Equality Act. It declared that it was unlawful to discriminate on the grounds of sex or marital status in recruitment for employment, conditions of employment, in training, in work experience, and in opportunities for promotion. In retrospect, the Marriage Bar in Ireland was effectively institutionalised gender discrimination. It is unclear how many women were affected by it. However, as is discussed below, we believe this number is not small, and it is certainly not the case that it only affected civil servants and teachers.

\section{Methodology}




\subsection{The Irish Longitudinal Study of Ageing}

As discussed above, the Marriage Bar in Ireland was abolished between 1973 and 1977. This is relatively late when compared to other countries. One of the consequences of this late abolition is that some of the women affected by it are still alive, and will be included in social surveys such as the European Social Survey, the Irish Social and Political Attitudes Survey and the Healthy Ireland Survey. However, we are only aware of one survey where respondents were asked questions about their personal experience of the Marriage Bar: The Irish Longitudinal Study on Ageing (TILDA). As detailed by Kearney et al. (2011), Cronin et al. (2013) and Whelan and Savva (2013), TILDA is a nationally representative sample of communitydwelling individuals aged 50 and above in Ireland. The survey collects detailed information on the economic, health, and social aspects of the respondents' lives. It is modeled closely on the USA Health Retirement Study (HRS), the English Longitudinal Study on Ageing (ELSA) and the multi-country Survey of Health, Retirement and Ageing in Europe (SHARE).

At wave 3 of data collection (2014/2015), TILDA female respondents who ever married and ever engaged in paid work were asked whether they ever had to leave a job because of the Marriage Bar. Interviewers were instructed to explain what the Marriage Bar was in case the respondent was unsure. The specific question asked is: "Did you ever have to leave a job because of the Marriage Bar?". Women affected by the Marriage Bar are the women who answered "Yes". Women not affected by the Marriage Bar are the women who answered "No". If women reported they had been affected by the Marriage Bar, they were asked to report which job it was that they had to leave and whether they ever returned to work.

The TILDA data is unique as it combines information about the Marriage Bar along with information on past circumstances and current aspects of the respondents' lives. Examples of past circumstances include education and childhood socio-economic conditions. Examples of current aspects are labour market status, level of income and wealth and health status at the time of interview. TILDA allows four key questions to be examined empirically for the first time with some rigour:

Q1: How many women were affected by the Marriage Bar in Ireland? 
Q2: Are there differences in the background characteristics of women affected and not affected by the Marriage Bar?

Q3: Which jobs in what sectors were affected by the Marriage Bar?

Q4: Are there differences in the long-term outcomes of women affected and not affected by the Marriage Bar?

The remainder of this paper is aimed at attempting to answer these questions with data from TILDA and other sources.

\subsection{Descriptive Analysis}

TILDA female respondents who ever married and ever engaged in paid work were asked whether they ever had to leave a job because of the Marriage Bar. "Younger" female respondents in TILDA were not at risk to the Marriage Bar since they entered the labour force after its abolition. Therefore, the analysis is restricted to women born before 1954. This resulted in a sample of 1,890 female respondents. The results reported below are robust to varying this cut-off year by a few years each way (available from the authors upon request). A total of 392 TILDA respondents reported that they had to leave their job because of the Marriage Bar. This corresponds to $21 \%$ of all women who ever married and ever engaged in paid work.

Table 1 reports descriptive statistics for a set of background characteristics of women included in our sample. These characteristics include the respondent's age (at time of survey) and her number of years of schooling completed. In addition, there are a set of characteristics aimed at proxying the respondent's socio-economic background when they were a child (i.e. at age 14). They are: self-reported poverty status, presence of books in the childhood home, amenities in childhood home, rural or urban location of childhood home, mother's employment status, father's employment status and number of siblings. The statistics are calculated separately for women affected and not affected by the Marriage Bar. A statistical test for the difference in the means between these two groups is also shown in the table.

$<<<$ Table 1 About Here $>>>>$ 
There are some statistically significant differences in these background characteristics between the two groups of women. More specifically, women affected by the Marriage Bar are about 3.5 years older than women who were not affected (i.e. 74.0 vs 70.6 years). Their level of education is also higher. The years of schooling completed for women affected by the Marriage Bar is about 0.7 years higher (i.e. 11.7 vs. 11.0 years). There are also some differences by socio-economic background. Most notably, self-reported poverty status is much lower for women affected by the Marriage Bar (i.e. $11.9 \%$ vs. $21.6 \%$ ). Women affected by the Marriage Bar were less likely to grow in homes with no or few books $(38.2 \%$ vs $45.5 \%)$ and with no amenities $(14.4 \%$ vs. $18.6 \%)$.

There is also a difference by location of childhood home. A smaller share of women affected by the Marriage Bar grew up in rural areas (51.4\% vs. 58.5\%). The mothers of those women who were affected by the Marriage Bar had higher rates of not working outside the household (i.e. $78.9 \%$ vs. $72.2 \%$ ). There is little difference between the two groups of women with respect to their father's employment status and number of siblings. The descriptive statistics presented in Table 1 suggest that women affected by the Marriage Bar are older, have more schooling and come from more favourable socio-economic backgrounds. Therefore, given these differences, it is important to control for them in any statistical analysis aimed at modelling Marriage Bar effects.

As discussed above, it is unclear how many women were affected by the Marriage Bar because of spill-over to other jobs not strictly covered by the Marriage Bar. Table 2 shows the occupation distribution for women who reported having to leave their job because of the Marriage Bar. About half were employed as clerks, typists, secretaries, telephonists or receptionists. The remaining half were spread across a range of occupations. About $20 \%$ of those affected by the Marriage Bar were in occupations such as sale assistants, waitresses, factory workers or dress-makers. A large share (nearly 14\%) were nurses and radiographers, which is consistent with health boards applying the Marriage Bar. Less than 4\% were teachers. This low share is expected since the Marriage Bar for teachers was abolished in 1958. Therefore not many teachers affected by the Marriage Bar would be in the TILDA sample, since they would be in their $80 \mathrm{~s}$ or $90 \mathrm{~s}$ at the time of interview. Also, the Marriage Bar did not apply to secondary-level teachers (Kiely and Leane, 2012). 
Table 2 also shows the sector distributions for women who reported having to leave their job because of the Marriage Bar. Three broad sectors are considered: (1) Public $=$ civil service, local authorities, health boards, schools supported by the Department of Education, emergency services, prison service, defence forces and noncommercial state bodies; (2) State-sponsored bodies $=$ commercial bodies (such as companies) beneficially owned, either completely or in majority, by the Irish Government; and (3) Private sector = all employers not included in (1) or (2). Statesponsored bodies include large employers such as are Ireland's national public transport provider (Córas Iompair Éireann), Electricity Supply Board and the Irish tourist board (Bord Failte). About $42 \%$ of those women who reported having to leave their job because of the Marriage Bar were in the public sector. About $8 \%$ were into the statesponsored bodies. This leaves that about half of all women in our sample who reported leaving their job because of Marriage Bar were in the private sector.

\subsection{Long-term Outcomes}

\subsubsection{Statistical Model}

The aim of Section 3.3 is to investigate whether there are differences in longterm outcomes of women affected and not affected by the Marriage Bar. We consider four groups of outcomes: (1) family-related; (2) labour market-related; (3) economicsrelated; and (4) health-related. The specific variables used to measure these outcomes are discussed below. In order to examine the impact of the Marriage Bar on these outcomes, variants of the following statistical model are estimated:

Outcome $=F($ MarBar, $\boldsymbol{X})$

Where "MarBar" is a dummy variable coded "1" if the woman self-reported she was affected by the Marriage Bar, and coded " 0 " if not; " $\mathrm{X}$ " is a vector of other variables thought to impact on long-term outcomes. These are the variables discussed in Table 1 and Section 3.2: age, years of schooling and childhood characteristics. "F" denotes function. For continuous outcomes, the function is linear (i.e. OLS regression). For dichotomous outcomes, the function is the cumulative normal distribution (i.e. probit regression). 


\subsubsection{Variables}

Details of the outcomes investigated are provided in Table 3. Family-related outcomes include number of children (NumChild); child education (ChildDegree) and respondent's current marital status (SepDiv). Child education is expressed as the ratio of number of children with a degree or higher to total number of children. Current marital status is captured with a dichotomous variable, which is equal to one if the respondent was separated or divorced at the time of interview, zero otherwise.

\section{$<<<<$ Table 3 About Here $>>>>$}

Labour-market related outcomes include working-life duration (WorkingLife) and retirement duration (RetDur). Working-life duration is the proportion of potential working-life span spent in employment. Potential working-life span is defined as age at time of interview minus age at labour market entry for women younger than sixty-five, and as sixty-five minus age at labour market entry for those older than sixty-five. Retirement duration is the number of years elapsed since the last job ended, calculated as age at time of interview minus age at which the respondent stopped working.

Economics-related outcomes include respondent's current individual weekly income (Income) and household wealth (Wealth). In TILDA, Information on individual income is collected through a series of questions covering labour income and income from social welfare, pensions, investment incomes and other sources. The questions are taken directly from the recent versions of the European Union Statistics on Income and Living Conditions (EU-SILC) questionnaire. The distribution of income from TILDA and EU-SILC are closely aligned (O'Sullivan et al., 2014). Household wealth is calculated as the sum of wealth from owner occupied residential property, savings on deposit, financial assets, cars, other residential property and other types of assets minus mortgage and non-mortgage debt. Individual income and household wealth are measured in Euros.

Health-related outcomes include respondent's current mental, cognitive and cardiovascular health. The two dimensions of mental health investigated are depressive symptoms (Depr) and life satisfaction (Sat). Depressive symptoms are measured using the abbreviated eight-item version of the "Centre for Epidemiological StudiesDepression scale" (Radloff, 1977). This test consists of questions relating to negative 
feelings (like feeling lonely or sad), positive thoughts (as feeling happy, enjoying life), somatic activity (like suffering from a restless sleep) and social contacts (interaction with people). Each of the eight items is measured on a four-point scale leading to a total score ranging from 0 to 24 , with higher scores indicating more depressive symptoms. Life satisfaction is assessed on a 7-point Likert scale. Respondents are instructed to say how much they agree or disagree with the statement "I am satisfied with my life". Alternatives range from (1) strongly agree to (7) strongly disagree.

Cognitive health $(\mathrm{Cog})$ is captured through a test of how quickly participants can think of words from a particular category, in this case naming as many different animals as possible in one minute. Successful performance on this test requires selfinitiated activity, organization and abstraction (categorizing animals into groups such as domestic, wild, birds, dogs) and set-shifting (moving to a new category when no more animals come to mind from a previous category). Cardiovascular health (Cardio) is a dichotomous variable, which is equal to one if the respondent has one or more cardiovascular conditions; zero otherwise. Examples of cardiovascular conditions are high blood pressure or hypertension, diabetes or high blood sugar, high cholesterol and heart troubles.

\subsubsection{Descriptive Statistics}

Summary statistics of all outcomes are presented in Table 3. The estimates indicate that there are statistically significant differences between women affected and not affected by the Marriage Bar for some, but not all, of the outcomes. Focusing first on family-related outcomes, women affected by the Marriage Bar were more likely to have more children and to have more educated children. The women affected by the Marriage Bar had on average 3.9 children, compared to 3.3 children for women not affected by the Marriage Bar $(\mathrm{p}<0.01)$. Around half of the children $(49.4 \%)$ of the women affected by the Marriage Bar had a degree or a higher level of qualification. This compares to $40.1 \%$ of children of women not affected by the Marriage Bar $(p<0.01)$. A total of $5.6 \%$ of women affected by the Marriage Bar were separated or divorced at the time of interview. This compares to $8.5 \%$ of women not affected by the Marriage Bar $(\mathrm{p}<0.10)$.

With respect to labour market-related outcomes, women affected by the Marriage Bar had, on average, shorter working lives and longer retirement durations. The women affected by the Marriage Bar had spent $44.5 \%$ of their potential working 
life in employment, compared to $56.5 \%$ for women not affected by the Marriage Bar $(p<0.01)$. Also, women affected by the Marriage Bar had not been working in the labour market for an average of 25.6 years. This compares to 17.5 years for women not affected by the Marriage Bar $(\mathrm{p}<0.01)$. Turning to the economics-related outcomes, women affected by Marriage Bar had lower individual income but higher household wealth. The weekly individual income of women affected by the Marriage Bar was 256 Euro, compared to 300 Euro for women not affected by the Marriage Bar $(p<0.01)$. The household wealth of women affected by the Marriage Bar was around 437,000 Euro. This compares to 353,000 Euro for women not affected by the Marriage $\operatorname{Bar}(p<0.10)$. Focusing finally on the health-related outcomes, there are no statistically significant differences in current health outcomes between the two groups of women.

\subsubsection{Regression Results}

Regression results are presented in Table 4 . Panel 1 in Table 4 shows the regression results for family-related outcomes; Panel 2 is for labour-market outcomes; Panel 3 is for economics-related outcomes and Panel 4 is for health-related outcomes. The natural logarithm of individual income and household wealth is taken in the regressions of Panel 3 to address the problem that the income and wealth variables are skewed. OLS regression is used for the outcomes measured as continuous variables. Probit regression is used for the outcomes measured as dichotomous ( 0 or 1$)$ variables.

Two different specifications for each outcome are estimated. The first specification includes controls for age and childhood characteristics. The second specification includes, controls for age, childhood characteristics and education. While it is clear that childhood circumstances are exogenous, it is less clear whether education is exogenous. The presence of the Marriage Bar might have influenced decisions relating to education. If it is exogenous, it should be included. If it is endogenous, it should not be included. Comparison of the two is a form of robustness checking. Endogeneity issues are discussed in detail in Section 4. For brevity, only estimates, measured as "marginal effects" of the Marriage Bar variable, are presented in the table.

$<<<<$ Table 4 About Here $>>>$

The regression results summarized in Table 4 confirm what is suggested by the descriptive statistics presented in Table 3. Four findings stand out. The first is that 
women affected by the Marriage Bar had more children and the children of women affected by the Marriage Bar had higher educational attainment, holding constant age, childhood circumstances and education. The women affected by the Marriage Bar had on average 0.5 more children. Being affected by the Marriage was associated with an increase of 5.8 percentage points in the proportion of children completing university. This effect is considerably larger at 9.9 percentage points when education is not controlled for.

The second finding is that the two groups of women differ in terms of labour market and economics outcomes, even after holding age, childhood circumstances and education constant. Being affected by the Marriage Bar was associated with a decrease of 11.2 percentage points in working-life duration and with an increase of 4.5 years in retirement duration. Both these effects are smaller when education is not controlled for, 10.0 percentage points and 4.1 years, respectively. It is clear that the Marriage Bar had an impact on the time spent working and not-working.

The third finding is that there are differences between women affected and not affected by the Marriage Bar in terms of their individual income and household wealth. It is important to remember this is income and wealth at the time of the survey. Since the income and wealth variables are transformed into natural logarithms, the regression coefficients can be easily transformed into percentage effects. More specifically, $\%$ effect $=[\exp (|\widehat{\beta}|)-1] x 100$ where $\hat{\beta}$ is the relevant regression coefficient. The results of Table 4 show that being affected by the Marriage Bar is associated with lower current income. The estimates are similar for both specifications. More specifically, income is $49 \%$ lower when education is excluded and $56 \%$ lower when it is included as a control variable. One might expect that this lower income is explained to some extent by the lower levels of work experience that women affected by the Marriage Bar have. Somewhat surprisingly, wealth is higher for women affected by the Marriage Bar. When education is not included as a control variable, wealth is $73 \%$ higher. When education is included, it is $55 \%$ higher.

The fourth finding relates to the health-related outcomes. For the four measures considered there are no statistically significant differences (even at the $10 \%$ level) between women affected and not affected by the Marriage Bar. We believe that this is an important finding. One might expect that being forced to leave employment at a young age has long-lasting negative effects on mental health. This does not appear to 
be the case. The estimates suggest that there are no differences with respect to overall life satisfaction and depression. There is also no difference with respect to cognition. This result is important because all these women are in the age group in which cognitive abilities tend to decline. While these three measures are "psychological", the cardiovascular variable we use is a physical measure. The results suggest that there are not differences between the two groups on this important health measure.

Testing statistically the potential mechanisms that explain why there are differences in long-term outcomes between women affected and not affected by the Marriage Bar is beyond the scope of this paper. We believe that to do this effectively, it would require data beyond what is collected in TILDA. It would almost certainly require a survey aimed at collecting detailed information about both groups of women. However, it is worth reflecting on some of the findings in Table 4 before turning to the investigation of whether the presence of the Marriage Bar altered women's behaviour in Section 4. Two findings are particularly interesting since to a certain extent both are controversial.

Our analysis indicates that women affected by the Marriage Bar have higher current wealth. In addition, they are more likely to have more and higher educated children. As shown in Table 1, women affected by the Marriage Bar have higher levels of education. Evidence shows that couples typically match positively on individual characteristics, such as age and education (Fernandez et al., 2005; Skyt Nielsen and Svarer, 2009). Put slightly differently, people tend to marry people who are similar to themselves. Therefore, it could be that women who were subsequently affected by the Marriage Bar married more educated men. Since education is a key determinant of earnings, one would expect the husbands of women affected by the Marriage Bar to have higher earnings than the husbands of women not affected by it. This could account for this wealth difference.

Unfortunately, this hypothesis cannot be tested with TILDA data. The main reason being that information on husband's education is collected only if the husband is also a participant in TILDA or if the woman is married at the time of interview, independently of whether the husband is also participating in TILDA or not. Husband's education is not collected if the woman is a widow, separated or divorced at the time of interview. In the sample used in the analysis in this paper, information on husband's education is collected for only around two thirds of respondents.

In regressions not presented, but available on request, a variable measuring 
husband's years of schooling is added to the list of control variables. It is found that being affected by the Marriage Bar is associated with an increase of 5.3 percentage points in the proportion of children completing university and with a $18 \%$ increase in household wealth. The two regression estimates are statistically significant but only at the 10 per cent level. Although these results are indicative of a possible "husband's effect" on current levels of wealth and children's education, it is difficult to draw clear conclusions because one third of observations are excluded from these regressions. Therefore it is unlikely that this sample is representative of the population of interest. It may also be the case that the traditional division of labour within couples might have become even more clear-cut in households where the wife was affected by the Marriage Bar, resulting in the husband working more and earning more that he would done had otherwise.

The results of Table 1 also show that women affected by the Marriage Bar are less likely to report they grew up in a poor household compared to women not affected by the Marriage Bar. Therefore, another possible explanation of higher levels of wealth among households where the wife was affected by the Marriage Bar is that the women affected by it - and perhaps their husbands - have received larger inheritances from their parents or relatives. Finally, as explained in Section 2, women affected by the Marriage Bar received a marriage gratuity at marriage. The gratuity could have amounted to one year of salary. One cannot exclude that the marriage gratuity was subsequently invested in the children's education and/or contributed to household wealth.

In summary, the analysis reported in this section, based on data from the TILDA survey, has shed light on some questions that have remained unanswered in the literature. First, the Marriage Bar affected a large proportion of women. Second, women affected by the Marriage Bar came from more favourable socioeconomic backgrounds. Third, the Marriage Bar was practiced in the private sector and across a range of occupations. Fourth, there is some impact of the Marriage Bar on long-term outcomes. For example, women affected by the Marriage Bar have shorter working lives, lower individual income, higher household wealth, more children and more educated children. However, it is important to stress that these effects are not all negative. 


\section{Endogeneity}

\subsection{Sources of Endogeneity}

It could be the case that the presence of the Marriage Bar altered the behaviour of women by influencing their decisions relating to marriage, education, and employment and occupational choice. There are at least three possible explanations for why this may be the case. The first is that women who did not marry were not affected by the Marriage Bar. Hence, one could argue that women married less to avoid having to resign at marriage. In this sense, some women may have chosen a career over marriage. The second reason is that the Marriage Bar ended the time many women spent in paid employment at a young age. Because of this, some women may have chosen to spend less time in formal education (or did not engage in paid employment after leaving education), as they knew their time in paid employment was going to be short. The third reason is that not all occupations were affected by the Marriage Bar. As a consequence, women may have avoided occupations that were affected by the Marriage Bar. If it is the case that the Marriage Bar did impact on such choices, the estimates of the effect of the Marriage Bar on long-term outcomes (discussed in Section 3) may be biased.

In order to investigate if the Marriage Bar affected the behaviour of women, one needs at least two cohorts or groups of women to compare. The first cohort is individuals who were making choices when the Marriage Bar was in place. That is, before the abolition of the Marriage Bar. The second cohort is individuals who were making choices when the Marriage Bar was not in place. That is, after the abolition of the Marriage Bar. If such cohorts are available, one can compare women's behaviour before and after the abolition of the Marriage Bar. This comparison cannot be made with rigour using micro-data from TILDA data, since it is a "cohort study" in the sense that the same women are re-interviewed is subsequent data waves.

Census data can be used for this purpose. In testing for endogeneity, we use published data from the six censuses in the period 1961 to 1991 - three censuses before the abolition of the Marriage Bar and three censuses after it - and micro-data from the 1971 and 1981 censuses. As is described in detail in Section 4.2, this data is used to investigate the hypothesis that women did alter their behaviour because of the Marriage Bar. The focus is on the behaviour of young people aged 15 to 24 years. We believe this is the age group whose behaviour is most likely to be affected by the Marriage Bar. 


\subsection{Statistical Tests for Endogeneity}

Two approaches are followed. The first approach is descriptive in the sense that it investigates trends in marriage, education, employment and type of occupation between 1961 and 1991. Most of the data used for this purpose comes from tables published in census reports (CSO, 1961-1991). Two groups of cohorts are identified: COHORT BEFORE and COHORT AFTER. COHORT BEFORE consists of three cohorts interviewed when the Marriage Bar was in place. COHORT AFTER consists of three cohorts interviewed after the Marriage Bar was abolished. With the exception of primary school teachers, the abolition of the Marriage Bar occurred between 1973 and 1977. Hence, the first three cohorts are drawn from the 1961, 1966 and 1971 censuses. The remaining three cohorts are drawn from the 1981, 1986 and 1991 censuses. If the Marriage Bar altered women's behaviour in the way one would expect, one should find that, compared to COHORT AFTER, women belonging to COHORT BEFORE married less, invested less in education, engaged less in paid employment and avoided occupations that were heavily affected by the Marriage Bar. Since being exposed or not to the Marriage Bar was not the only difference between COHORT BEFORE and COHORT AFTER, trends for females are compared to trends for males.

The second approach uses regression analysis based on individual micro-data from the two cohorts that were interviewed just before (1971) and just after (1981) the abolition of the Marriage Bar. The 1971 and 1981 census micro-data is drawn from the International Census Public Use Micro Samples (IPUMS) for Ireland, which includes $10 \%$ of all census records (Minnesota Population Center, 2018). A "difference-indifference" approach is adopted to model outcomes capturing behaviour in (1) marriage; (2) education; (3) employment; and (4) type of occupation. The specific variables used to discuss these outcomes are discussed below. The "difference-indifference" approach is used to estimate the effect of the abolition of the Marriage Bar by comparing changes in outcomes over time - which is before and after the abolition of the Marriage Bar - between females and males. See Lechner (2011) for a detailed survey of these methods.

In our application, women are the treatment group as they were exposed to the Marriage Bar in 1971, but not in 1981. Men are the control group as they were never exposed to the Marriage Bar. A regression model of this form is estimated: 
Where Female is a dummy variable coded " 1 " if the individual was female; 0 if male. Census is a dummy variable coded " 1 " if the individual was interviewed in the 1981 census; 0 if she was interviewed in the 1971 census. Female*Census is the interaction between the two dummy variables. $\mathbf{X}$ is a vector of background characteristics. Unfortunately, as the census is not as rich in background characteristics as TILDA, only two variables are included in vector $\mathbf{X}$ in Eq. (2). These are AgeGroup and PlaceBirth. AgeGroup is a dummy variable equal to one if the individual was aged 2024 at the time of census interview; 0 if she was aged 15-19. PlaceBirth is a categorical variable equal to 1 if the individual was born in Dublin; equal to 2 if she was born in the rest of Ireland; and equal to 3 if she was born abroad.

The outcomes under investigation in Eq. (2) are: Married, InEducation; InEmployment, ClerkTypist and Teacher. Married is a dummy variable equal to " 1 " if the individual was married at the time of the census interview and " 0 " if they were not. InEducation is a dummy variable equal to " 1 " if the individual was in education at the time of the census interview, "0" if they were not. InEmployment is a dummy variable equal to " 1 " if the individual was in employment at the time of the census interview, and " 0 " if they were not in the labour force or unemployed. ClerkTypist is a dummy variable equal to "1" if the individual was employed as a clerk or typist at the time of the census interview; and " 0 " if they were employed but in another occupations. Teacher is a dummy variable equal to " 1 " if the individual was employed as a teacher at the time of the census interview; and " 0 " if they were employed but in another occupations.

The analysis of Section 3.2 suggests that clerks and typists were heavily affected by the Marriage Bar, both in the public and the private sector. Also the people employed in these occupations were mostly women. Hence, we argue that clerks and typists are a particularly relevant occupation to examine. Teachers are also a relevant occupation to examine, although for the opposite reason. The Marriage Bar in teaching was abolished in 1958. This implies that young women interviewed in the 1971 and 1981 census waves were too young to be affected by the Marriage Bar in teaching. For this reason, comparing results for ClerkTypist and Teacher is informative. As all the five outcomes are dichotomous, probit regression is used in the regression analysis.

The estimate of interest is the marginal effect of the interaction term between 
Female and Census. As explained by Ai and Norton (2003 and 2004) and Puhani (2012), computing the marginal effect of an interaction term is more complicated in nonlinear models as compared to linear models. In our application, we follow the methodology of Karaca-Mandic et al. (2012) and exploit the flexibility of the command margins in the statistical software STATA 12 to compute the marginal effect of the interaction term between Female and Census. This is calculated as the marginal effect of Female in the 1981 Census minus the marginal effect of Female in the 1971 census. Results from the descriptive analysis and from the regression analysis are discussed in Sections 4.2.1 to 4.2.4.

\subsubsection{Endogeneity of Marriage?}

The first source of potential endogeneity investigated is marriage: Did the Marriage Bar alter women's marriage behaviour? Were women marrying less when the Marriage Bar was in place? If women were marrying less when the Marriage Bar was in place, one would expect that the marriage rate increased after the abolition of the Marriage Bar. No evidence in support of this hypothesis is found.

Figure 1 shows the trends in the crude and general marriage rates in the period 1926-1996. General marriage rate is defined as number of marriages per 1,000 female population aged $15+$. Crude marriage rate is defined as number of marriages per 1,000 population. Figure 1 shows that the marriage rate stabilized and then decreased after the abolition of the Marriage Bar. A similar trend is observed in Figure 2. Trends in marriage rates for COHORT BEFORE (1961-1971) and COHORT AFTER (1981-1991) are shown for individuals aged 15 to 24 . Also for this age group, the marriage rate stabilized and then decreased after the abolition of the Marriage Bar.

$<<<<$ Figures 1 and 2 about here $>>>>$

Results for the estimate of interest of the difference-in-difference regression model of Eq. (2) are presented in Table 5. Two specifications are used. The first specification does not include the controls for age and place of birth. The second specification includes them. The results of Column 1, Table 5 show that the average change in the predicted probability of being married in the 1981 census as compared to the 1971 census was 0.5 to 0.9 percentage points lower for women compared to men. This suggest that, if anything, women were less likely to marry than men after the 
abolition of the Marriage Bar as compared to before the abolition of the Marriage Bar. This finding is exactly opposite to what one would expect to find if women were marrying less when the Marriage Bar was in place.

$$
<<<<\text { Table } 5 \text { About Here }>>>>
$$

\subsubsection{Endogeneity of Education?}

The second source of potential endogeneity is education: Did the Marriage Bar alter women's education behaviour? Were women investing less in education when the Marriage Bar was in place? If women were investing less in education when the Marriage Bar was in place, one would expect to observe a sizable discontinuity (increase) in female education, but not in male education, after the abolition of the Marriage Bar. No strong evidence in support of this hypothesis is found.

Figure 3 shows the trends in years of education completed for males and females aged 15 to 24 in the period 1950 to 2015. These data come from the Barro-Lee Educational Attainment Dataset (Barro and Lee, 2013). The figure shows nearly parallel trends in education levels for males and females until recent years. For both males and females, education levels increased until the early 1980s, decreased in the following two decades and increased thereafter. The average number of years of schooling completed increased from 7.1 to 12.4 for females between 1950 and 2015. The corresponding figures for males are 6.4 and 13.7 years, respectively. A similar trend is shown in Figure 4. Trends in the proportion of females and males in education for COHORT BEFORE (1966-1971) and COHORT AFTER (1981-1991) are shown. The proportion of females in education increased from $23.2 \%$ in 1966 to $47.8 \%$ in 1991. The corresponding figures for males are $23.3 \%$ and $44.6 \%$. The figure suggests that there is no discontinuity by sex between COHORT BEFORE and COHORT AFTER.

$<<<<$ Figures 3 and 4 About Here $>>>>$

The results of the difference-in-difference regression model of Column 2 of Table 5 show that the average change in the predicted probability of being in education in the 1981 census as compared to the 1971 census was around 2 percentage points higher for women that for men. This means that females aged 15 to 24 were 2 
percentage points more likely to be in education than males in the same age group after the abolition of the Marriage Bar as compared to before the abolition of the Marriage Bar. We argue that 2 percentage points is a small difference. If the Marriage Bar did affect educational choice, its effect was small.

\subsubsection{Endogeneity of Employment?}

The third source of potential endogeneity is employment: Did the Marriage Bar alter women's employment behaviour? A note of caution is needed. The Marriage Bar was the requirement that women leave employment at marriage in certain jobs. As the aim of the analysis is to investigate whether the Marriage Bar altered women's employment behaviour, and not to investigate the extent to which the Marriage Bar was binding, only single women (and single men) are included. The questions we want to address are: did the Marriage Bar alter women's employment behaviour before marriage? Were single women engaging less in employment when the Marriage Bar was in place? If single women were engaging less in employment when the Marriage Bar was in place, one would expect to observe a sizable discontinuity (increase) in the female employment rate, but not in the male employment rate, after the abolition of the Marriage Bar. No strong evidence in support of this hypothesis is found.

Trends in employment rates for COHORT BEFORE (1961-1971) and COHORT AFTER (1981-1991) are shown in Figure 5. Employment rates for both single males and single females decreased in the period in focus. The proportion of single females aged 15 to 24 in employment decreased from $56.2 \%$ in 1961 to $35.3 \%$ in 1991 . The corresponding proportions for men are $63.7 \%$ and $38.4 \%$, respectively. No discontinuity by sex is observed between COHORT BEFORE and COHORT AFTER.

\section{$<<<<$ Figure 5 About Here $>>>$}

The results of the difference-in-difference regression model of Column 3 of Table 5 show that the average change in the predicted probability of being in employment in the 1981 census as compared to the 1971 census was very similar in magnitude for single women and single men. This means that single women were as likely to be in employment as single men after the abolition of the Marriage Bar as compared to before the abolition of the Marriage Bar. 


\subsubsection{Endogeneity of Occupation?}

The fourth source of potential endogeneity is occupation: Did the Marriage Bar affect women's occupation choice before marriage? Were single women avoiding jobs which were affected by the Marriage Bar? If single women were avoiding jobs affected by the Marriage Bar, one would expect employment rates for single women in occupations affected by the Marriage Bar to be on a downward trend when the Marriage Bar was in place. One would also expect to find a sizable discontinuity (increase) in proportion of females employed in occupations affected by the Marriage Bar, but not in the proportion of males employed in the same occupations, after the abolition of the Marriage Bar. No strong evidence in support of these hypotheses is found.

Clerks and typists are a particularly relevant occupation group to examine since this occupation was heavily affected by the Marriage Bar. Trends in the proportions employed as clerks and typists for COHORT BEFORE (1961-1971) and COHORT AFTER (1981-1991) are shown in Figure 6. The figure shows that many more single women were employed as clerks or typists than single men. This is not surprising as these were predominantly female occupations. Also, the proportion of single women employed as clerks or typists increased over time when the Marriage Bar was in place. A total of $20.7 \%$ of women in employment were working as clerks or typists in 1961. This compares to $31.6 \%$ in 1971 . These two findings indicate that single women were not avoiding to work as clerks or typists when the Marriage Bar was in place. The proportion of those in employment working as clerks or typists increased after the abolition of the Marriage Bar, for both men and women, before starting to decrease. A likely explanation for the decrease in the proportions of single individuals employed as clerks or typists in the 1986 and 1991 cohorts is that less jobs were available for younger single individuals since female clerks and typists who married were no longer forced to leave employment at marriage.

$<<<<$ Figure 6 About Here $>>>$

The results of the difference-in-difference regression model of Column 4 of Table 5 show that the average change in the predicted probability of being employed as a clerk or typist in the 1981 census as compared to the 1971 census was 4.8 to 5.4 percentage points higher for single women than for single men. This means that young 
single women were 4.8-5.4 percentage points more likely to be employed as clerks or typists after the abolition of the Marriage Bar than young single men as compared to before the abolition of the Marriage Bar. Clerks and typists were predominantly female occupations and as shown in Figure 6 the proportion of single women working as clerks and typists was already on the rise when the Marriage Bar was in place. Hence, we argue that the greater increase for single women as compared to single men between 1971 and 1981 is most likely explained by the underlying expansion of the service sector in the economy. For example, a total of $43 \%$ of all men and women in employment were employed in the service sector in 1971 . This increased to $51 \%$ in 1981 (CSO, 2000, pp .147-148).

As explained in Section 4.2, teachers are also a particularly relevant occupation to examine, although for the opposite reason. The Marriage Bar in teaching was abolished in 1958, so much earlier than the total abolition in 1973. This implies that the Marriage Bar in teaching could not have influenced the occupational choice of young women interviewed in the 1971 and 1981 census waves. In simple terms, young women interviewed in the 1971 and 1981 census waves were "too young" to be affected by the Marriage Bar in teaching. Trends in the proportions employed as teachers for COHORT BEFORE (1961-1971) and COHORT AFTER (1981-1991) are shown in Figure 7. The number of teachers aged 15 to 19 is very low, for obvious reasons. Therefore, trends for single teachers aged 20 to 29 are shown. Reassuringly, Figure 6 and 7 show that the employment trends for both clerks and typists and teachers are similar in the period under consideration.

$<<<$ Figure 7 About Here $>>>$

The results of the difference-in-difference regression model of Column 5 of Table 5 show that the predicted probability of being employed as a teacher in the 1981 census as compared to the 1971 census was around 1.9 percentage points higher for young single women than for young single men. This implies that as compared to men, single women were more likely to be employed not only as clerks or typists but also as teachers in 1981 than in 1971. This confirms that changes in occupational trends between 1971 and 1981 were not only driven by the abolition of the Marriage Bar, but also by other forces, such as the increasing trend in female participation and the expansion of the service sector. 


\section{Conclusion}

The Irish Longitudinal Study on Ageing is the first nationally-representative study that asks respondents questions about their personal experience of the Marriage Bar. Analysis of the data has generated three main findings. The first is that the Marriage Bar was widespread. Around one fifth of women who ever married and ever engaged in paid work in the TILDA sample reported they had to leave a job because of the Marriage Bar. The second finding is that the Marriage Bar was not confined to specific sectors or occupations. It was applied in both the private and public sector and in both manual and non-manual occupations. The third finding is that there is some impact of the Marriage Bar on what can be termed "long-term outcomes". Our statistical analysis shows that there are some differences in long-term outcomes between women affected and not affected by the Marriage Bar. Most notably, women affected by the Marriage Bar have shorter working lives, lower individual income but higher household wealth at the time of interview, more children and more educated children. However, there appear to be no differences in the physical, mental and cognitive health at time of interview between women affected and not affected by the Marriage Bar.

It should be stressed that the analysis of these findings can only be "trusted" if the Marriage Bar did not have any major impact on the marriage, education, employment and occupation behaviour of women. Evaluating the potential endogeneity of these variables is important. In our evaluation, we compared trends in marriage, education, employment, and type of occupation of two cohorts of individuals. The first cohort is individuals who were making choices when the Marriage Bar was in place. The second cohort is individuals who were making choices when the Marriage Bar was not in place. Census published data and census micro-data were used for this purpose.

We find no clear evidence that the Marriage Bar altered women's behaviour that is we believe decisions regarding marriage, educational attainment, employment and occupational choices to be exogenous. We are, therefore, confident that our findings of the long-term impacts of the Marriage Bar are not biased. One could argue that the finding that the Marriage Bar did not alter women's behaviour in any major way is surprising. However, it is important to remember that the norms and societal expectations in terms of the roles of men and women in Ireland at the time are very 
different from today's norms and expectations. In O'Leary's (1987, p. 51) words “the history of the [Irish] Marriage Bar cannot be understood in isolation from the society that produced it".

The consequences of the Marriage Bar is a serious topic of current debate. It should not be forgotten that many of the women affected by it are still alive. One outcome of the Marriage Bar is that it created a group of women who do not have the minimum number of contributions needed to qualify for a (full) state pension. This is because they had to leave employment at relatively young ages and many did not return to the labour market for many years (if at all). This outcome was a central concern in the Green Paper on Pensions (DFSA, 2007). Its publication was followed by a consultation exercise where the public was invited to express their views on any of the topics discussed in it. A very large number of submissions were about the pension consequences of the Marriage Bar (DFSA, 2008).

The Irish government responded to the submissions raised by the women affected by the Marriage Bar two years later, in the 2010 National Pension Framework. The conclusion of the Framework was that "the Government cannot address shortcomings which have arisen from gaps in social insurance coverage in the past" (DFSA, 2010, p. 26). In December 2017, the Minister of Finance Pascal Donohoe was asked to clarify the government's position on the pension consequences of the Marriage Bar. Mr Donogue reinforced that the government cannot compensate the women affected by the Marriage Bar. He also referred to the Marriage Bar as a "bonkers law" and stated that "the way those women were treated was wrong" (The Irish Times, 2017).

It is difficult to estimate how many women were affected by the Marriage Bar in Ireland. In the 2010 National Pension Framework, the Irish Government estimated that there were 47,000 older individuals who at the time did not have enough contributions to qualify for the state pension (DFSA, 2010, p. 25). Two groups of individuals were identified. The first group are "mainly former civil servants" affected by the Marriage Bar. The second group are self-employed individuals affected by gaps in social insurance coverage, which existed until the 1980s. The relative shares of the two groups was not given. We believe that the number of women not qualifying for a (full) state pension because of the Marriage Bar might be higher. More specifically, in 2011, there were a total of 292,079 women aged 65 and older in Ireland (CSO, 2012). A total of $19.5 \%$ of all women aged 65 and above interviewed in the third wave of 
TILDA reported they had to leave a job because of the Marriage Bar. This implies that in 2011 potentially up to 57,000 women were not qualifying for a (full) state pension because of the Marriage Bar.

It is also important to remember that a share of the women affected by the Marriage Bar are dead. Most likely, these are women who were required to leave employment in the 1920s and 1930s. Other women might still be alive but might not be represented in surveys. For example, the baseline TILDA sample (2010) did not include women living in nursing homes and women who were cognitively impaired. This implies that any estimation of the number of women affected by the Marriage Bar based on women who are still alive will by default exclude women who have already died or who are not represented in surveys. However, it is our view that all women who were affected by the Marriage Bar should not be forgotten.

We have shown the Marriage Bar had an impact on income levels in later life whereby women affected by the Marriage Bar have lower incomes than those not affected by it. This is likely driven by the fact that they experienced a sizeable reduction in their lifetime earnings. There are at least three reasons for this. The first is that many women were required to leave paid employment when they were young. This is the period when the experience-earnings profile is at its steepest and the growth of earnings is the most pronounced. In other words, women were required to leave employment in the period that has a large impact on their lifetime earnings. The second reason is that women affected by the Marriage Bar have, on average, less work experience. It is an established fact that there is a positive relationship between work experience and earnings. Individuals with lower work experience have a lower earnings potential. Therefore, women with lower work experience (for whatever reason) have lower lifetime earnings.

The third reason is that skills rewarded in the labour market depreciate. It is also an established fact that there is a negative relationship between time spent not working and earnings. It is argued that skills depreciate or become outdated if they are not used. Therefore, the negative consequences of the Marriage Bar is not only the loss of earnings associated with not working but also the loss of earnings potential caused by depreciation. Couple these reasons with the known fact that many women affected by the Marriage Bar do not qualify for a full state pension, the case for compensation is even more compelling. 
It is also important to note that it is possible to estimate the earnings loss caused by the Marriage Bar. However this cannot be done with TILDA data on its own. The approach, which is standard in labour economics, requires the estimation of earnings equations for women. These equations empirically generate so-called "earnings profiles", which is a description (at its simplest) of the relationship between schooling, work experience (i.e. time spent in the labour market working for pay) and so-called "home time" (i.e. time not spent in the labour market). Since women affected by the Marriage Bar, on average, have less work experience and more home time, the earnings loss of both can be estimated from the shape (slopes) of the earnings profiles. There is data available in Ireland that could be used to estimate the necessary earnings equations. While this is not a technically difficult task, it is not a trivial task either, and is an academic paper in its own right. Therefore, we leave it for other researchers to write.

In conclusion, it is important to stress once again that many of the women affected by the Marriage Bar are still alive. However, as every year passes, there are fewer and fewer of them. Given prevailing mortality rates, in a decade from now there will only be a small number who are still alive. Since Marriage Bars were abolished much earlier in other countries, these Irish women are perhaps the last sizeable living group of women subject to what was effectively legal institutionalized gender discrimination. We believe that analysing the impacts of the Marriage Bar is important for both academic and social justice reasons. We also believe that collecting more information should be a research priority. This will require a dedicated survey of women both affected and not affected by the Marriage Bar. The clock is ticking so action not intent is needed now in this respect. 


\section{References}

Ai, C. and E. Norton (2003). "Interaction terms in logit and probit models". Economics Letters, 80: 123-129

Barro, R. and J.W. Lee (2013). "A new data set of educational attainment in the world, 1950-2010". Journal of Development Economics, 104(184-198)

Connolly, E. (2003). "Durability and change in state gender systems. Ireland in the 1950s". The European Journal of Women's Studies, 10(1): 65-86

CSO (Central Statistics Office) (1926-2000). Annual reports on marriages, births and deaths in Ireland from 1864 to 2000. Dublin: Government of Ireland. Retrieved from https://www.cso.ie/en/statistics/birthsdeathsandmarriages/archive/annualreportsonmarri agesbirthsanddeathsinirelandfrom 1864 to2000/

CSO (Central Statistics Office) (1961-1991). Historical census reports. Retrieved from https://www.cso.ie/en/census/censusvolumes1926to1991/historicalreports/

CSO (Central Statistics Office) (2000). That was then, this is now. Change in Ireland, 1949-1999. Stationery Office, Dublin

CSO (Central Statistics Office) (2012). This is Ireland: Highlights from census 2011, part 1 (Report). Dublin, Ireland: Stationery Office. Retrieved from https://www.cso.ie/en/census/census2011reports/census2011thisisirelandpart1/

CSW (Commission on the Status of Women) (1972). Report of the Commission on the status of women. Dublin: Stationery Office

Cronin, H., C. O’Regan, P. Kearney et al. (2013). "Health and ageing: development of the TILDA health assessment". Journal of the American Geriatrics Society, 61(s2): 269-278 
DSFA (Department of Social and Family Affairs) (2007). Green Paper on Pensions. Dublin, Government of Ireland

DSFA (Department of Social and Family Affairs) (2008). Report on the consultation process for the Green Paper on Pensions. Final Report. Dublin, Government of Ireland

DSFA (Department of Social and Family Affairs) (2010). National Pensions Framework. Dublin, Government of Ireland

Fernández, R., N. Guner and J. Knowles (2005). "Love and money: A theoretical and empirical analysis of household sorting and inequality". The Quarterly Journal of Economics, 120(1): 273-344

Goldin, C. (1990). Why did change take so long? In C. Goldin \& C. Dale (Eds.), Understanding the gender gap: an economic history of American women (pp. 159184). New York, NY: Oxford University Press

Karaca-Mandic, P., E.C. Norton and B. Dowd (2012). "Interaction terms in nonlinear models". Health Services Research, 47(1 Pt 1): 255-274

Kearney, P.M., Cronin, H., O'Regan, C., et al. (2011). "Cohort profile: the Irish longitudinal study on ageing”. International Journal of Epidemiology, 40(4): 877-884

Kiely, E., \& Leane, M. (2012). Irish women at work, 1930-1960: an oral history. Dublin, Ireland: Irish Academic Press

Lechner, M. (2011). "The estimation of causal effects by difference-in-difference methods". Foundations and Trends in Econometrics, 4(3): 165-224

Minnesota Population Center (2018). Integrated Public Use Microdata Series, International: Version 7.1 [dataset]. Minneapolis, MN: IPUMS. Retrieved from https://doi.org/10.18128/D020.V7.1 
Muldowney, M. (2007) The second world war and Irish women: an oral history. Dublin, Portland, OR. Irish Academic Press

Norton, E.C, H. Wang and C. Ai (2004). “Computing interaction effects and standard errors in logit and probit models". The Stata Journal, 4(2): 154-167

O’Leary, E. (1987). “The Irish national teachers' organisation and the Marriage Bar for women national teachers, 1933-1958”. Saothar, 12: 47-52

O’Sullivan, V., B. Nolan, A. Barrett and C. Dooley (2014). "Income and wealth in The Irish Longitudinal Study on Ageing”. Economic and Social Review, 45(3): 329-348

Puhani, P.A. (2012). "The treatment effect, the cross difference, and the interaction term in nonlinear "difference-in-differences"' models". Economics Letters, 115: 88-87

Redmond, J. and J. Harford (2010). "One man one job": the marriage ban and the employment of women teachers in Irish primary schools". Paedagogica Historica, 45(5): 639-654

The Irish Times (1975). From the archives: June 13 ${ }^{\text {th }}$, 1975. Retrieved from https://www.irishtimes.com/culture/tv-radio-web/from-the-archives-june-13th-19751.2245973

The Irish Times (2017). How did thousands of women lose out on their State pensions?. Retrieved from https://www.irishtimes.com/business/personal-finance/how-did-thousands-of-womenlose-out-on-their-state-pensions-1.3254079

The Journal (2014). Did you (or your mother) have to give up work on getting married?. Retrieved from https://www.thejournal.ie/giving-up-work-when-married-1852776-Dec2014/

The Spectator (1946). The Marriage Bar, Retrieved from http://archive.spectator.co.uk/article/23rd-august-1946/2/the-marriage-bar 
Radloff, L.S. (1977). “The CES-D scale: a self-report depression scale for research in the general population”. Applied Psychological Measurement, 1(3): 385-401

Russell, H., F. McGinnity and P. O’Connell, P. (2017). “Gender equality in the Irish labour market 1966-2016: unfinished business?". The Economic and Social Review, 48(4): 393-418

Skyt Nielsen H. and M. Svarer (2009). "Educational homogamy: how much is opportunities?". The Journal of Human Resources, 44 (4): 1066-1086

Walsh, B. (1971). "Aspects of labour supply and demand with special reference to the employment of women in Ireland". Journal of the Statistical and Social Inquiry Society of Ireland, 22 (3): 88-123

Whelan, B.J. and G.M. Savva (2013). "Design and methodology of the TILDA study". Journal of the American Geriatrics Society, 61 (s2): 265-268 


\begin{tabular}{|c|c|c|c|c|c|c|}
\hline \multicolumn{7}{|c|}{$\begin{array}{c}\text { Table } 1 \\
\text { Background Characteristics }\end{array}$} \\
\hline & & & (1) & $(2)$ & (3) & (4) \\
\hline Mnemonic & Definition & Measurement & $\begin{array}{c}\text { Mean } \\
\text { (St. Dev.) }\end{array}$ & $\begin{array}{c}\text { Mean } \\
\text { (St. Dev.) } \\
\text { if } \\
\text { MarBar=1 } \\
\end{array}$ & $\begin{array}{c}\text { Mean } \\
\text { (St. Dev.) } \\
\text { if } \\
\text { MarBar=0 }\end{array}$ & $\begin{array}{l}p \text { value }(\%) \\
\text { of test } \\
(3)-(2)=0\end{array}$ \\
\hline MarBar & Marriage Bar & $\begin{array}{l}\text { Dummy: } 1 \text { for affected by Marriage Bar; } 0 \\
\text { for not affected by the Marriage Bar }\end{array}$ & $20.8 \%$ & -- & -- & -- \\
\hline Age & $\begin{array}{l}\text { Age of respondent at time of } \\
\text { survey }\end{array}$ & Years & $\begin{array}{l}71.9 \\
(8.2)\end{array}$ & $\begin{array}{l}74.0 \\
(8.0)\end{array}$ & $\begin{array}{l}70.6 \\
(7.8)\end{array}$ & $<1 \%$ \\
\hline School & Schooling of respondent & Years completed & $\begin{array}{l}11.1 \\
(2.4)\end{array}$ & $\begin{array}{l}11.7 \\
(2.2) \\
\end{array}$ & $\begin{array}{l}11.0 \\
(2.3)\end{array}$ & $<1 \%$ \\
\hline PoorFam & $\begin{array}{l}\text { Self-reported poverty in } \\
\text { childhood }\end{array}$ & Dummy: 1 for poor; 0 for average/well-off & $19.6 \%$ & $11.9 \%$ & $21.6 \%$ & $<1 \%$ \\
\hline NoBooks & $\begin{array}{l}\text { Number of books in childhood } \\
\text { home }\end{array}$ & Dummy: 1 for $0-10$ books; 0 for $11+$ books & $44.0 \%$ & $38.2 \%$ & $45.5 \%$ & $1 \%$ \\
\hline NoAmen & $\begin{array}{l}\text { Number of amenities in } \\
\text { childhood home }\end{array}$ & $\begin{array}{l}\text { Dummy: } 1 \text { for no amenities (e.g. no inside } \\
\text { toilet; no central heating; no electricity); } 1 \\
\text { for } 1+\text { amenities }\end{array}$ & $17.7 \%$ & $14.4 \%$ & $18.6 \%$ & $10 \%$ \\
\hline Rural & $\begin{array}{l}\text { Rural/urban location of } \\
\text { childhood home }\end{array}$ & Dummy: 1 for rural area; 0 for urban area & $57.0 \%$ & $51.4 \%$ & $58.5 \%$ & $5 \%$ \\
\hline MotherNotWork & Mother's employment status & $\begin{array}{l}\text { Dummy: } 1 \text { for mother never worked; } 0 \\
\text { otherwise }\end{array}$ & $73.6 \%$ & $78.9 \%$ & $72.2 \%$ & $5 \%$ \\
\hline FatherNotWork & Fathers's employment status & $\begin{array}{l}\text { Dummy: } 1 \text { for father never worked; } 0 \\
\text { otherwise }\end{array}$ & $7.1 \%$ & $5.5 \%$ & $7.6 \%$ & $>10 \%$ \\
\hline Siblings & Siblings & Number of sisters and brothers & $\begin{array}{c}5.2 \\
(3.0)\end{array}$ & $\begin{array}{l}5.0 \\
(2.9)\end{array}$ & $\begin{array}{c}5.3 \\
(3.0)\end{array}$ & $>10 \%$ \\
\hline
\end{tabular}


Table 2:

Occupations and Sectors of Employment of Jobs Left because of the Marriage Bar

\begin{tabular}{|c|c|}
\hline Occupations & Share \\
\hline 1. Clerk, typist, secretary, telephonist, receptionist, book keeper & $51.8 \%$ \\
\hline 2. Nurse, radiographer & $13.8 \%$ \\
\hline 3. Teacher & $3.6 \%$ \\
\hline 4. Sale assistant, cashier & $7.4 \%$ \\
\hline 5. Waitress, cook, hairdresser, domestic service & $6.1 \%$ \\
\hline 6. Factory worker, general operative, machine operator, packer & $8.2 \%$ \\
\hline 7. Dress maker & $2.8 \%$ \\
\hline 8. Other & $6.4 \%$ \\
\hline Total $(\mathrm{N}=392)$ & $100 \%$ \\
\hline \multicolumn{2}{|l|}{ Sector: } \\
\hline 1. Public & $41.8 \%$ \\
\hline 2. State-sponsored & $7.7 \%$ \\
\hline 3. Private & $50.5 \%$ \\
\hline Total $(\mathrm{N}=392)$ & $100 \%$ \\
\hline
\end{tabular}




\begin{tabular}{|c|c|c|c|c|c|c|c|}
\hline \multicolumn{8}{|c|}{$\begin{array}{c}\text { Table } 3 \\
\text { Descriptive Statistics for Outcome Variables }\end{array}$} \\
\hline & & & (1) & $(2)$ & (3) & (4) & (5) \\
\hline Mnemonic & Definition & Measurement & $\begin{array}{c}\text { Mean } \\
\text { (St. Dev.) }\end{array}$ & $\begin{array}{l}\text { Mean } \\
\text { (St. Dev.) } \\
\text { if } \\
\text { MarBar=1 }\end{array}$ & $\begin{array}{l}\text { Mean } \\
\text { (St. Dev.) } \\
\text { if } \\
\text { MarBar=0 }\end{array}$ & $\begin{array}{l}p \text { value of } \\
\text { test } \\
(3)-(2)=0\end{array}$ & $\begin{array}{c}\text { Max } \\
\text { number } \\
\text { of cases }\end{array}$ \\
\hline \multicolumn{8}{|c|}{ 1.Family-related variables } \\
\hline NumChild & Family size & Number of children & $\begin{array}{l}3.5 \\
(2.0)\end{array}$ & $\begin{array}{c}3.9 \\
(2.0)\end{array}$ & $\begin{array}{c}3.3 \\
(1.9)\end{array}$ & $<0.01$ & 1,890 \\
\hline ChildDegree & $\begin{array}{l}\text { Children with degree or } \\
\text { higher }\end{array}$ & $\begin{array}{l}\text { Ratio of number of children with degree or higher to total } \\
\text { number of children }\end{array}$ & $42.1 \%$ & $49.4 \%$ & $40.1 \%$ & $<0.01$ & 1,777 \\
\hline SepDiv & Marital status & Dummy: 1 for separated or divorced; 0 otherwise & $7.9 \%$ & $5.6 \%$ & $8.5 \%$ & 0.08 & 1,890 \\
\hline \multicolumn{8}{|c|}{ 2.Labour market-related variables } \\
\hline WorkingLife & $\begin{array}{l}\text { Time spent in } \\
\text { employment }\end{array}$ & $\begin{array}{l}\text { Ratio of number of years spent in employment since labour } \\
\text { market entry to: i) age at time of interview for respondents } \\
\text { aged }<=65 \text {; ii) } 65 \text { for respondents aged }>65\end{array}$ & $53.4 \%$ & $44.6 \%$ & $56.5 \%$ & $<0.01$ & 1,798 \\
\hline RetDur & $\begin{array}{l}\text { Retirement duration } \\
\text { defined as time elapsed } \\
\text { since last job }\end{array}$ & $\begin{array}{l}\text { Age at time of interview minus age respondent stopped } \\
\text { working, in years }\end{array}$ & $\begin{array}{c}19.2 \\
(18.6)\end{array}$ & $\begin{array}{c}25.6 \\
(21.7)\end{array}$ & $\begin{array}{c}17.5 \\
(17.3)\end{array}$ & $<0.01$ & 1,727 \\
\hline \multicolumn{8}{|c|}{ 3.Economics-related variables } \\
\hline Income & $\begin{array}{l}\text { Weekly individual } \\
\text { income at time of } \\
\text { interview }\end{array}$ & $\begin{array}{l}\text { Sum of income from work, social welfare, pensions, } \\
\text { investment and other sources; in Euros }\end{array}$ & $\begin{array}{c}291.3 \\
(495.3)\end{array}$ & $\begin{array}{c}256.1 \\
(281.4)\end{array}$ & $\begin{array}{c}300.1 \\
(488.0)\end{array}$ & 0.01 & 1,675 \\
\hline Wealth & $\begin{array}{l}\text { Net household wealth at } \\
\text { time of interview }\end{array}$ & $\begin{array}{l}\text { Sum of wealth from owner occupied residential property, } \\
\text { savings on deposit, financial assets, cars, other residential } \\
\text { property and other types of assets minus mortgage and non- } \\
\text { mortgage debt; in Euros }\end{array}$ & $\begin{array}{c}371,680 \\
(654,807)\end{array}$ & $\begin{array}{c}436,887 \\
(661,914)\end{array}$ & $\begin{array}{c}353,922 \\
(652,042)\end{array}$ & 0.06 & 1,387 \\
\hline \multicolumn{8}{|c|}{ 4. Health-related variables } \\
\hline Depr & Mental health & CES-D depression score, ranging between 0 and 24 & $\begin{array}{c}3.7 \\
(4.0)\end{array}$ & $\begin{array}{l}3.6 \\
(3.9)\end{array}$ & $\begin{array}{c}3.7 \\
(4.0)\end{array}$ & 0.67 & 1,847 \\
\hline
\end{tabular}




\begin{tabular}{|c|c|c|c|c|c|c|c|}
\hline Sat & Life satisfaction & $\begin{array}{l}\text { Response to statement "I am satisfied with my life", ranging } \\
\text { between } 1 \text { (strongly agree) and } 7 \text { (strongly disagree) }\end{array}$ & $\begin{array}{c}2.0 \\
(1.3)\end{array}$ & $\begin{array}{l}1.9 \\
(1.3)\end{array}$ & $\begin{array}{c}2.0 \\
(1.3)\end{array}$ & 0.54 & 1,882 \\
\hline $\operatorname{Cog}$ & Cognitive health & Number of animals named by respondent in a minute & $\begin{array}{l}17.2 \\
(5.3)\end{array}$ & $\begin{array}{l}16.8 \\
(5.1)\end{array}$ & $\begin{array}{l}17.3 \\
(5.4)\end{array}$ & 0.16 & 1,853 \\
\hline Cardio & Cardiovascular health & $\begin{array}{l}\text { Dummy: } 1 \text { for has } 1 \text { or more cardiovascular conditions; } 0 \\
\text { otherwise }\end{array}$ & $70.6 \%$ & $73.0 \%$ & $70.0 \%$ & 0.27 & 1,852 \\
\hline
\end{tabular}

Source: TILDA wave 3 (2014/2015) 
Table 4

Regression Estimates: Long-term Outcomes

\section{Panel 1: Family-related outcomes}

\begin{tabular}{|l|c|c|c|}
\hline & $(1)$ & $(2)$ & $(3)$ \\
\hline & NumChild $^{a}$ & ChildDegree $^{a}$ & SepDiv $^{b}$ \\
\hline Not controlling for education & $0.487^{* * *}$ & $0.099^{* * *}$ & -0.015 \\
\hline & $(0.131)$ & $(0.025)$ & $(0.019)$ \\
\hline Controlling for education & $0.530^{* * *}$ & $0.058^{* *}$ & -0.013 \\
\hline & $(0.132)$ & $(0.023)$ & $(0.019)$ \\
\hline
\end{tabular}

Panel 2: Labour market-related outcomes

\begin{tabular}{|l|c|c|l|l|}
\hline & $(1)$ & $(2)$ & & \\
\hline & WorkingLife $^{a}$ & RetDur $^{a}$ & & \\
\hline Not controlling for education & $-0.100^{* * *}$ & $4.067^{* * *}$ & & \\
\hline & $(0.019)$ & $(1.219)$ & & \\
\hline Controlling for education & $-0.112^{* * * *}$ & $4.465^{* * *}$ & & \\
\hline & $(0.019)$ & $(1.208)$ & & \\
\hline & & & & \\
\hline
\end{tabular}

Panel 3: Economics-related outcomes

\begin{tabular}{|l|c|c|l|l|}
\hline & $(1)$ & $(2)$ & & \\
\hline & $\ln \left(\right.$ Income $^{a}$ & $\ln (\text { Wealth })^{a}$ & & \\
\hline Not controlling for education & $-0.400^{* *}$ & $0.547^{* * *}$ & & \\
\hline & $(0.166)$ & $(0.116)$ & & \\
\hline Controlling for education & $-0.443^{* * *}$ & $0.435^{* * *}$ & & \\
\hline & $(0.169)$ & $(0.111)$ & & \\
\hline
\end{tabular}

\section{Panel 4: Health-related outcomes}

\begin{tabular}{|l|c|c|c|c|}
\hline & $(1)$ & $(2)$ & $(3)$ & $(4)$ \\
\hline & Depr $^{a}$ & LifeSat $^{a}$ & Cog $^{a}$ & Cardio $^{b}$ \\
\hline Not controlling for education & -0.026 & 0.001 & -0.123 & 0.006 \\
\hline & $(0.243)$ & $(0.081)$ & $(0.309)$ & $(0.029)$ \\
\hline Controlling for education & 0.079 & 0.011 & -0.385 & 0.013 \\
\hline & $(0.245)$ & $(0.082)$ & $(0.315)$ & $(0.029)$ \\
\hline & & & & \\
\hline
\end{tabular}

Notes: Reported estimates are marginal effects of MarBar. Standard errors are in parentheses. ${ }^{a}$ : OLS regression is used. ${ }^{b}$ : Probit regression is used. *** $\mathrm{p}<0.01 ;{ }^{* *} \mathrm{p}<0.05 ;{ }^{*} \mathrm{p}<0.1$ All regression include controls for age and childhood circumstances (see text).

Source: TILDA wave 3 (2014/2015) 


\begin{tabular}{|c|c|c|c|c|c|}
\hline \multicolumn{6}{|c|}{$\begin{array}{c}\text { Table } 5 \\
\text { Difference-in-difference Probit Regression Estimates }\end{array}$} \\
\hline & \multicolumn{4}{|c|}{ Outcome Z: } & \\
\hline & (1) & (2) & (3) & (4) & (5) \\
\hline & Married & InEducation & InEmployment & ClerkTypist & Teacher \\
\hline \multicolumn{6}{|c|}{ Panel 1: no controls are added } \\
\hline \multirow[t]{2}{*}{ Marg. Effect } & -0.005 & $0.019 * * *$ & -0.007 & $0.054 * * *$ & $0.019 * * *$ \\
\hline & $(0.004)$ & $(0.006)$ & $(0.006)$ & $(0.007)$ & $(0.004)$ \\
\hline \multicolumn{6}{|c|}{ Panel 2: controls for age and place of birth are added } \\
\hline \multirow[t]{2}{*}{ Marg. Effect } & $-0.009 * *$ & $0.021 * * *$ & -0.008 & $0.048 * * *$ & $0.019 * * *$ \\
\hline & $(0.004)$ & $(0.005)$ & $(0.006)$ & $(0.007)$ & $(0.004)$ \\
\hline \multicolumn{6}{|c|}{$\begin{array}{l}\text { Notes: Estimates are marginal effects of the interaction between Female and Census } 1981 \text { (see text). Standard } \\
\text { errors in parentheses. Delta method is used to compute standard errors. Statistical significance: *** } p<0.01 \text {; ** } \\
\text { p }<0.05 \text {; and } * \text { p }<0.1 \\
\text { Source: Minnesota Population Center }(2018)\end{array}$} \\
\hline
\end{tabular}


Figure 1: Crude and general marriage rate

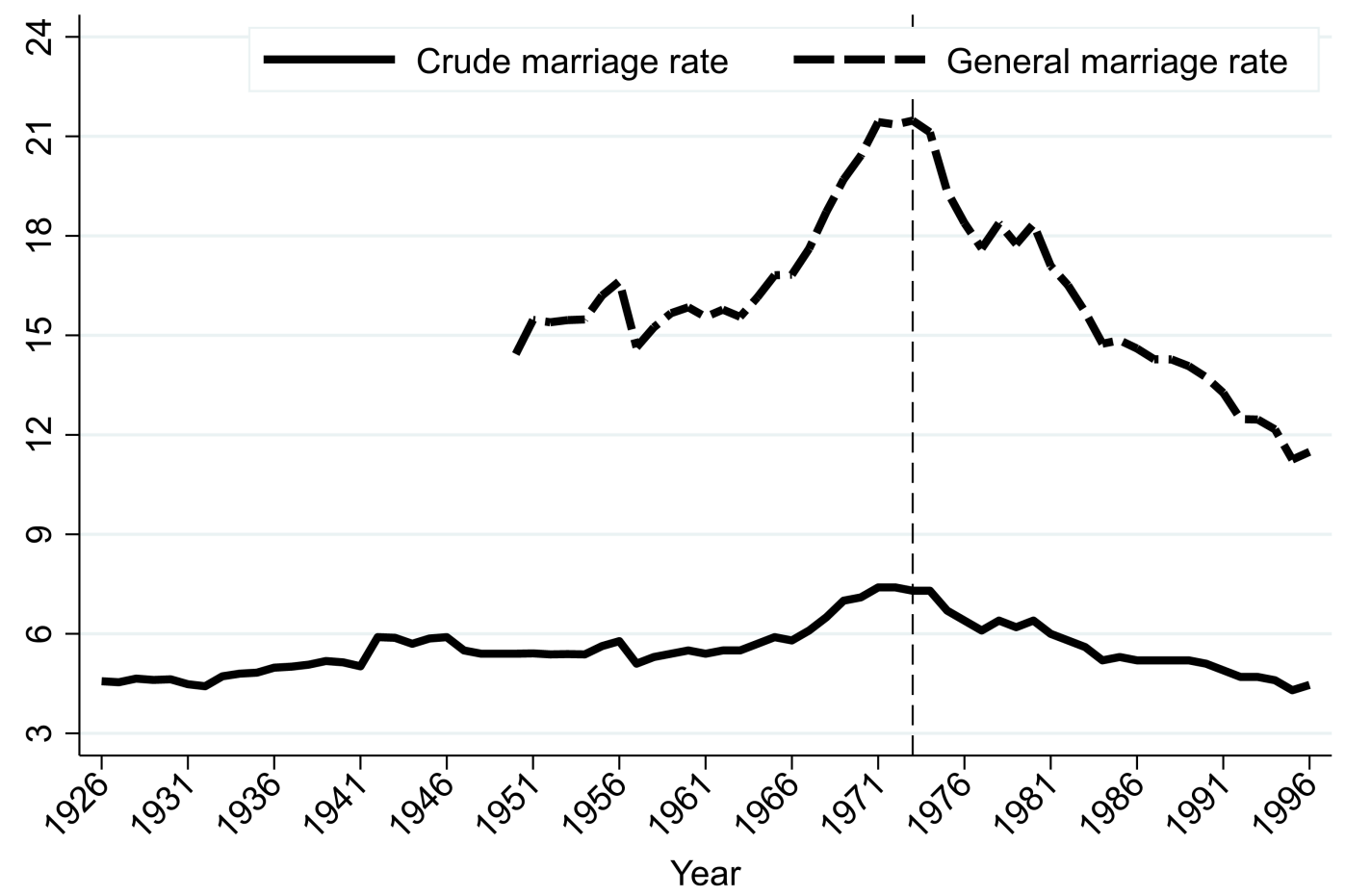

Note: Vertical dotted line marks 1973 abolition of the Marriage Bar Source: CSO, 1926-2000 
Figure 2: Historical trends in proportion married for COHORT BEFORE (1961-1971) and COHORT AFTER (1981-1991), ages 15-24

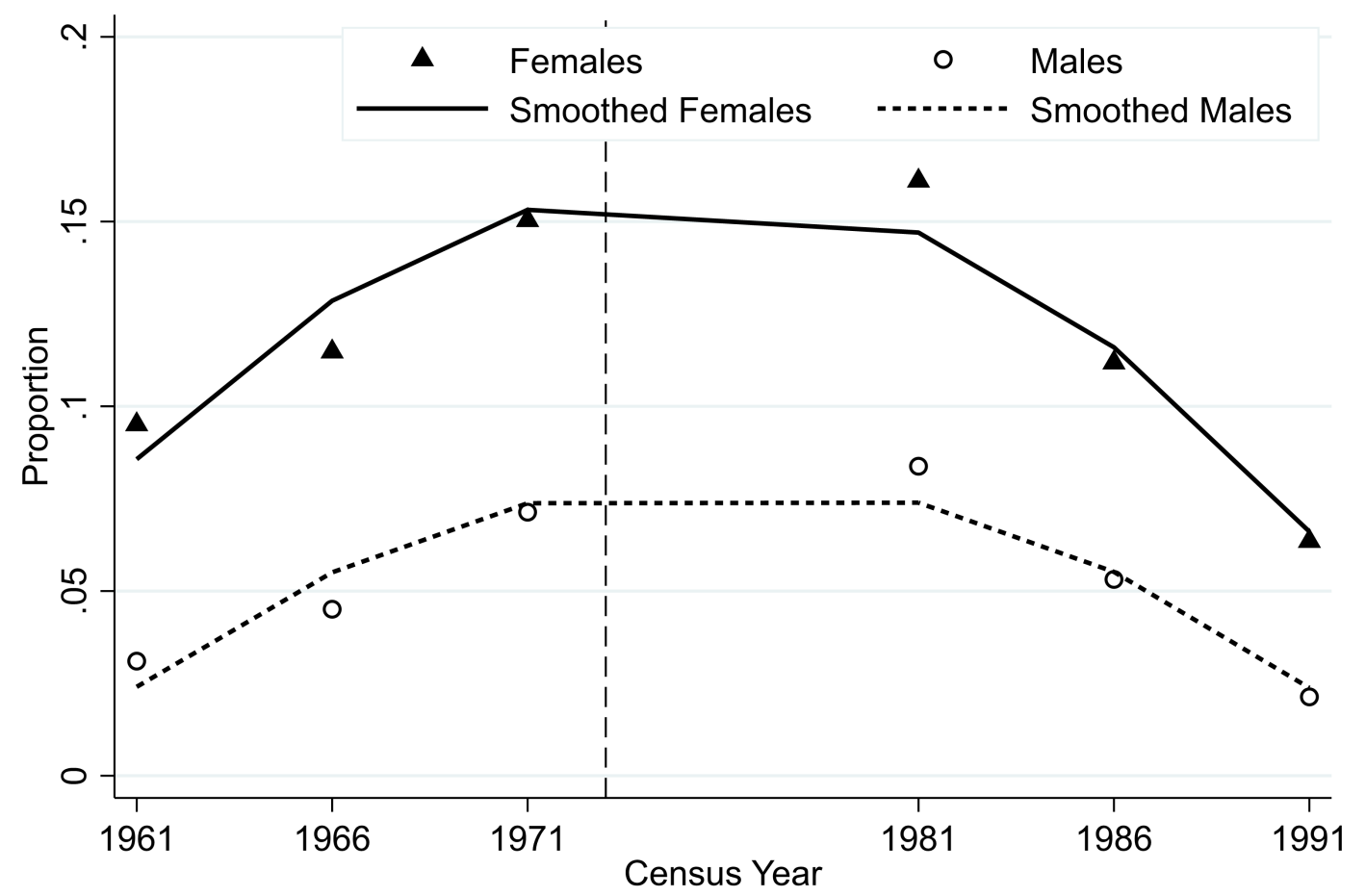

Note: Smoothed using fractional polynomial regression. Vertical dotted line marks 1973 abolition of the Marriage Bar. Source: CSO 1961-1991 
Figure 3: Historical trends in years of schooling completed

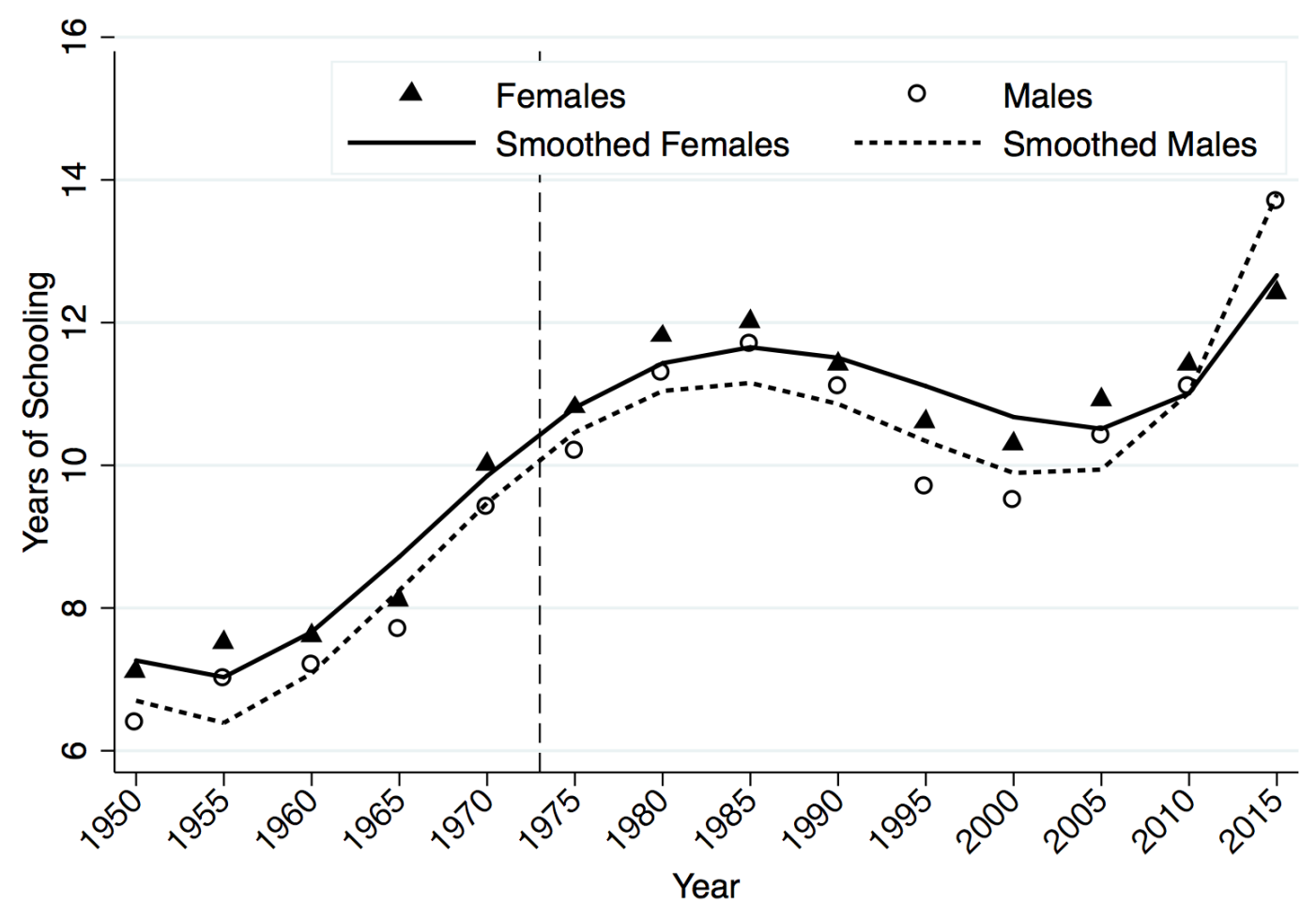

Note: Smoothed using kernel-weighted local polynomial. Vertical dotted line marks 1973 abolition of the Marriage Bar Source: Barro and Lee, 2013 
Figure 4: Historical trends in proportion in education for COHORT BEFORE (1966-1971) and COHORT AFTER (1981-1991), ages 15-24

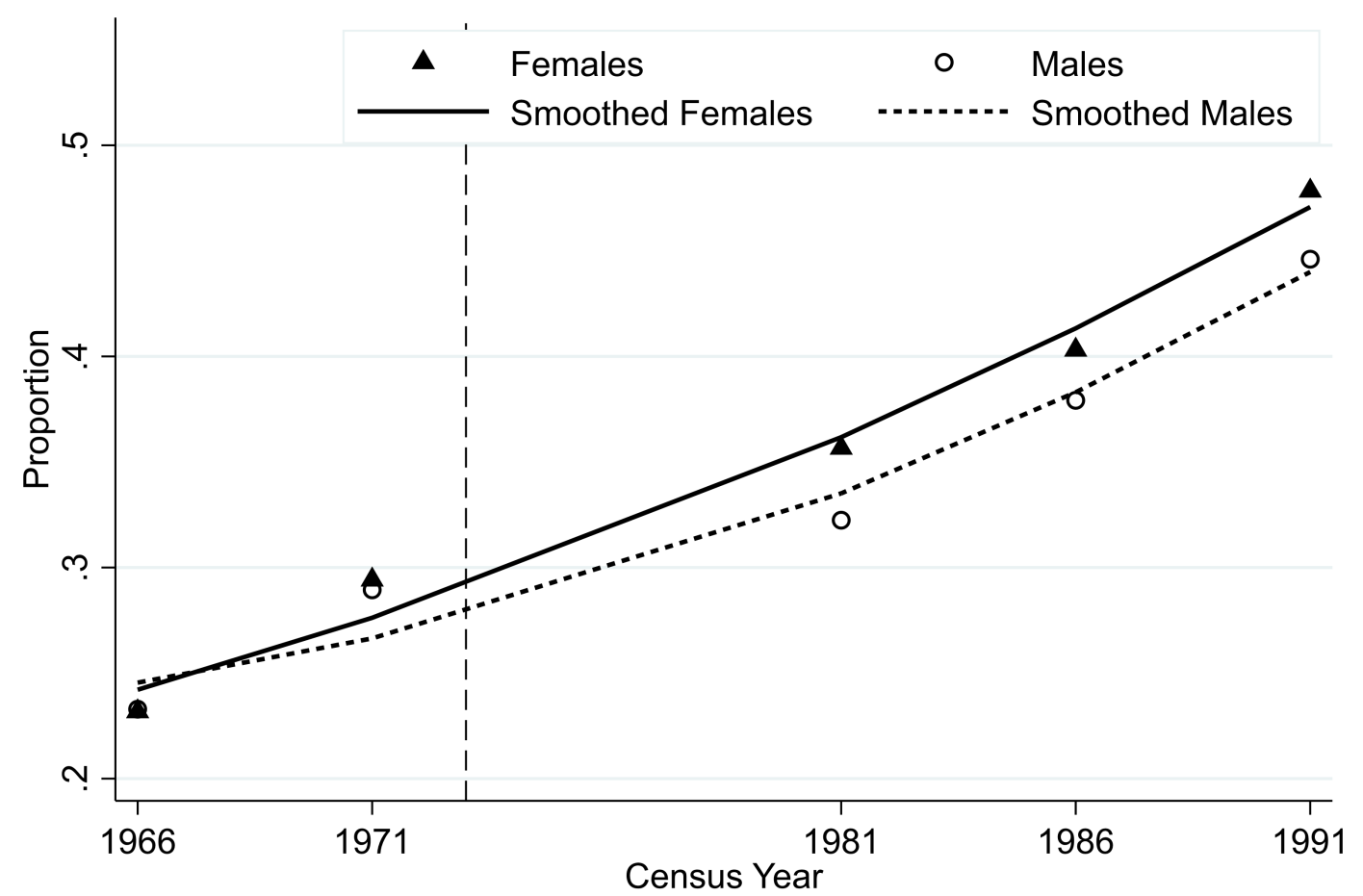

Note: Smoothed using fractional polynomial regression. Vertical dotted line marks 1973 abolition of the Marriage Bar. Source: CSO, 1961-1991 
Figure 5: Historical trends in proportion in employment for COHORT BEFORE (1961-1971) and COHORT AFTER (1981-1991), ages 15-24

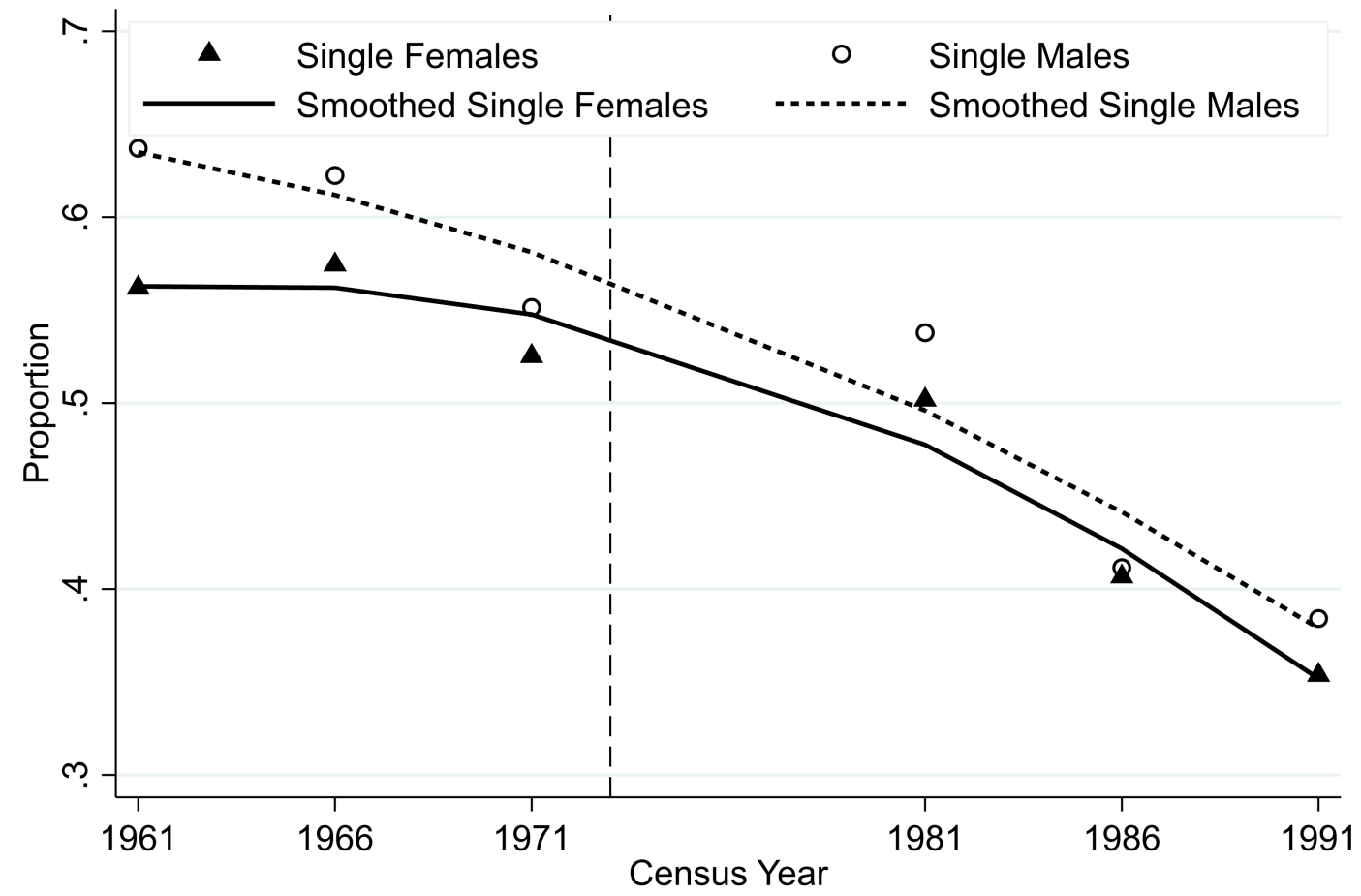

Note: Smoothed using fractional polynomial regression. Vertical dotted line marks 1973 abolition of the Marriage Bar. Source: CSO, 1961-1991 
Figure 6: Historical trends in proportion employed as clerks or typists for COHORT BEFORE (1961-1971) and COHORT AFTER (1981-1991), ages 15-24

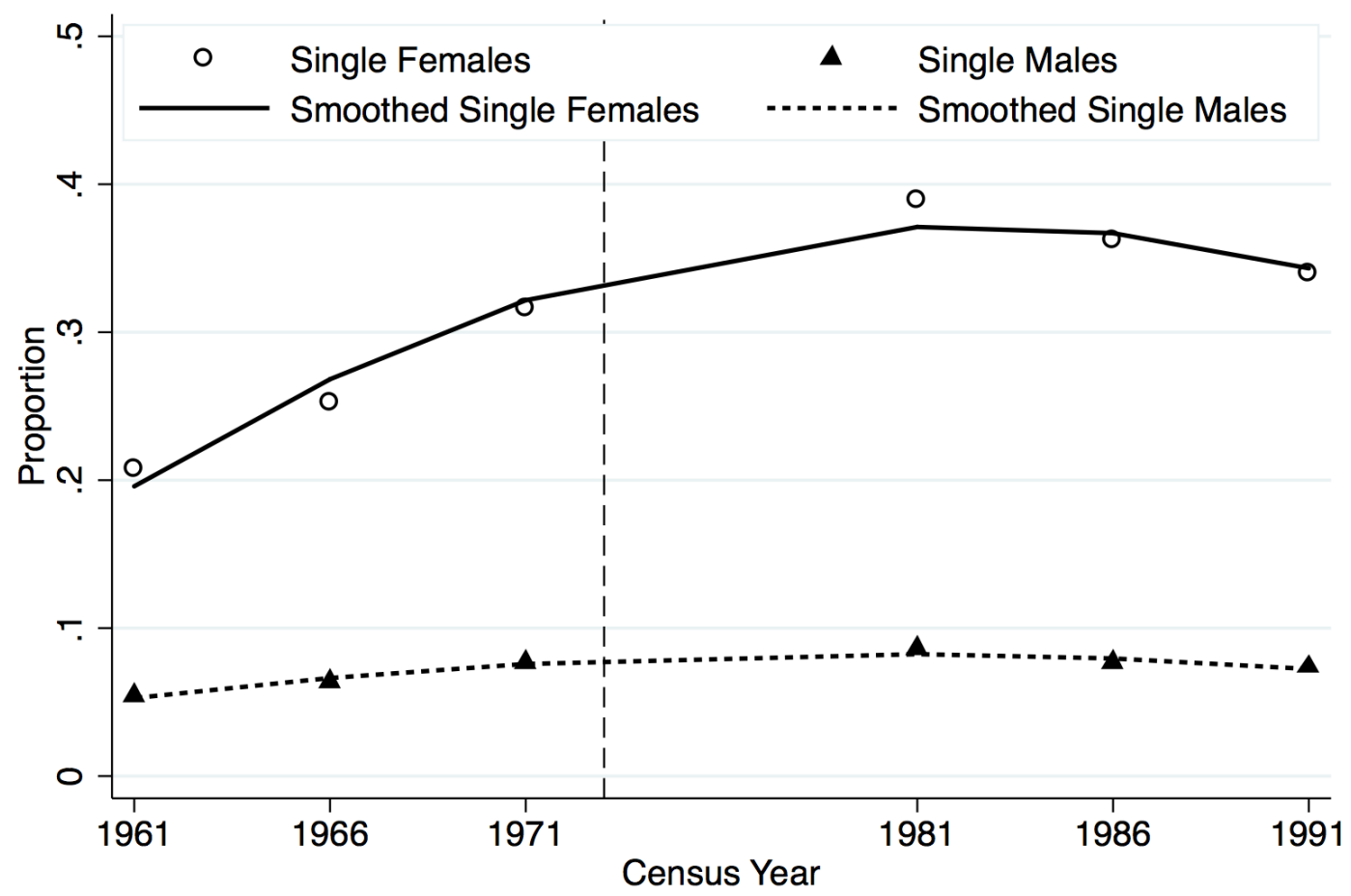

Note: Smoothed using fractional polynomial regression. Vertical dotted line marks 1973 abolition of the Marriage Bar. Source: CSO, 1961-1991 
Figure 7: Historical trends in proportion employed as teachers for COHORT BEFORE (19611971) and COHORT AFTER (1981-1991), ages 20-29

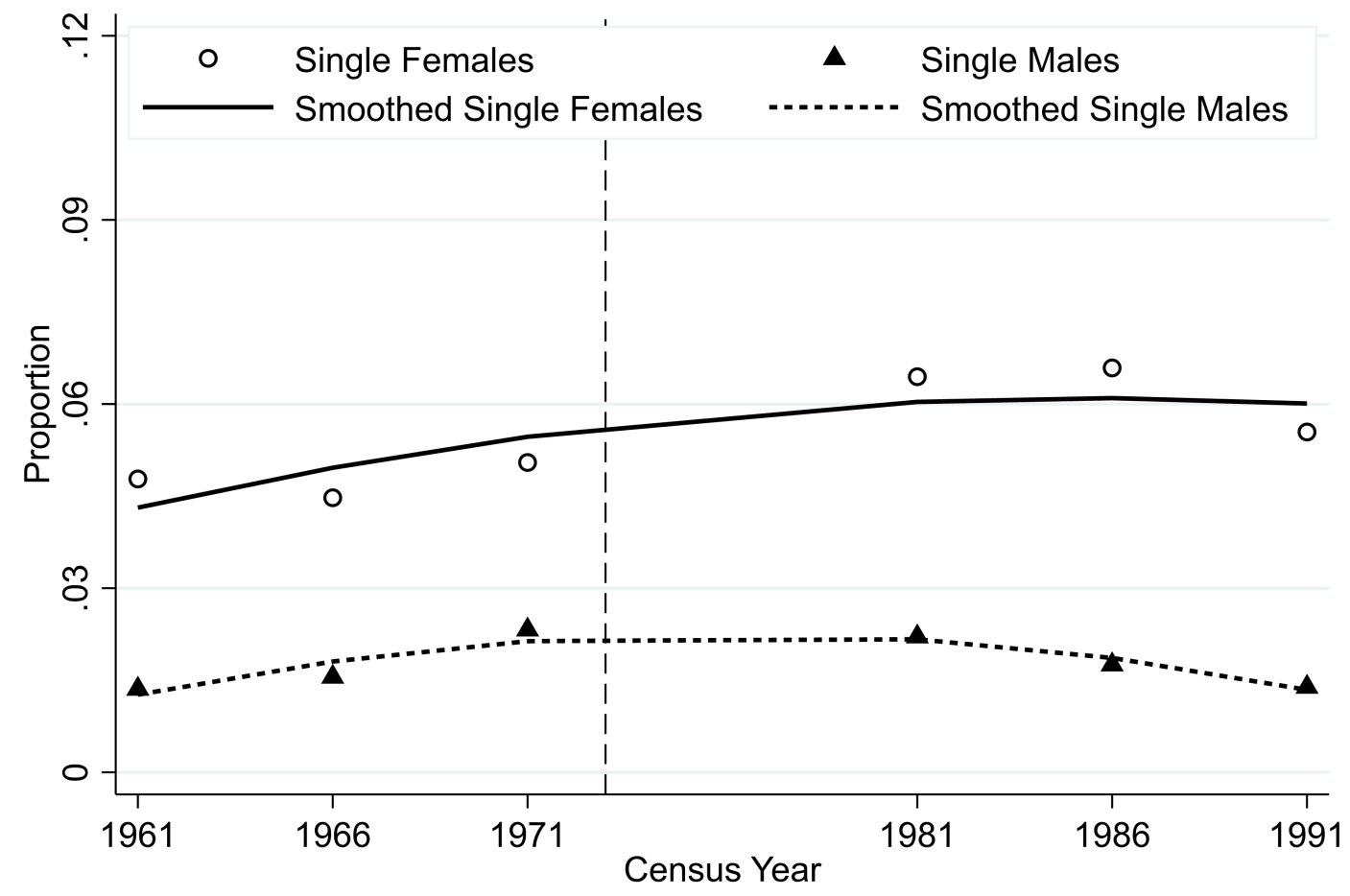

Note: Smoothed using fractional polynomial regression. Vertical dotted line marks 1973 abolition of the Marriage Bar. Source: CSO, 1961-1991 